\title{
A new Nyceryx Boisduval (Lepidoptera, Sphingidae) from Central Brazil
}

\author{
Vitor O. Becker ${ }^{1}$
}

\begin{abstract}
Nyceryx brevis sp. $\mathbf{n}$., is described from Central Brazil. KEY WORDS. Sphingidae, Nyceryx, Cerrado, Brazil, Neotropical
\end{abstract}

After over 30 years of intensive collecting in Central Brazil, five species of sphinx moths belonging to Nyceryx Boisduval, [1875], were recorded by the author: N. alophus (Boisduval, [1875]), N. coffeae (Walker, 1856), N. continuus (Walker, 1856), and two endemic undescribed species. One of the last two was described as Nyceryx furtadoi HAXAIRE (1996: 351) based on specimens collected in the states of Mato Grosso and Goiás, Central Brazil. The other is being described here. The type material is deposited in the author's collection, Brasília, Distrito Federal.

\section{Nyceryx brevis sp. $\mathbf{n}$.}

Figs 1-3

Male (Fig. 1), fore wing lenght 2-2.2 cm. Head, thorax, fore wings and abdomen covered with brown, whitish-tipped scales. Head with a dark brown band dorsally, which continues to mid thorax; palpi brown, $2^{\text {nd }}$ segment with a conspicuous silvery-white dot distally. Thorax and base of abdomen dark brown subdorsally; tegulae dark brown, edged white posteriorly; tibiae and tarsi white dorsaly. Fore wings with irregular, oblique, subrectangular patch from below cell to mid dorsum, connected to mid costa by a double fascia; a pair of dots at end of cell: a lower, proximal, large, and a distal, small at upper end of cell; three parallel, sinuous lines beyond dots and before postmedial fascia, from costa to dorsum; postmedial fascia dark brown, forming an even arch from apex to tornus; cilia concolorous, pale basally. Hind wings ochreous, tinged reddish brown; termen darkening gradually towards tornus; double graysh, arched, bands near tornus; dorsum ochreous, tinged reddish brown. Underside of both wings reddish brown; three ill-defined, sinuous lines beyond distal $3^{\text {rd }}$; graysh towards termen.

Male genitalia (Figs 2-3). Uncus bifid, covered with long setae. Gnathos bifid, lateral arms ending in a long, twisted, sharp-pointed process. Juxta tubular, densely covered with spines dorsally. Saccus long, tappering proximally. Valvae long; margins nearly parallel; sacculus well developed, extending to proximal $3^{\text {rd }}$ of valvae. Aedoeagus (Fig. 3), long, thin, cylindrical; apex extending into a very long, wip-shaped process, bearing dorsal spines at regular intervals, except distally where the spines are closer to each other.

1) Research Associate, Departamento de Zoologia, Universidade de Brasília. P.O. Box 04525 , 70919-970 Brasília, Distrito Federal, Brasil. E-mail: vbecker@rudah.com.br 
Holotype male. BRAzIL, Bahia: Morro do Chapéu, 1400 m, 23-24.IV.1991, Becker leg. [78175]. Paratypes. 1 male, same data as holotype; 1 male, Minas Gerais, Belo Horizonte, [Retiro das Pedras], 1300 m, 2.I.1976, Becker, leg. [18273].

Remarks. This is the smallest species in the genus. Its pattern resembles that of $N$. continuus (Walker, 1856), but is easily distinguished by its small size, less than two-thirds the size of the former.

This is either a very rare species or it is not readily attracted to light. After 30 years of intensive collecting in Central Brazil, only the three specimens listed above were collected. Both collecting localities, despite being much appart, are similar: both are located on top of rocky elevations covered with scattered low savanna trees, and bushes.

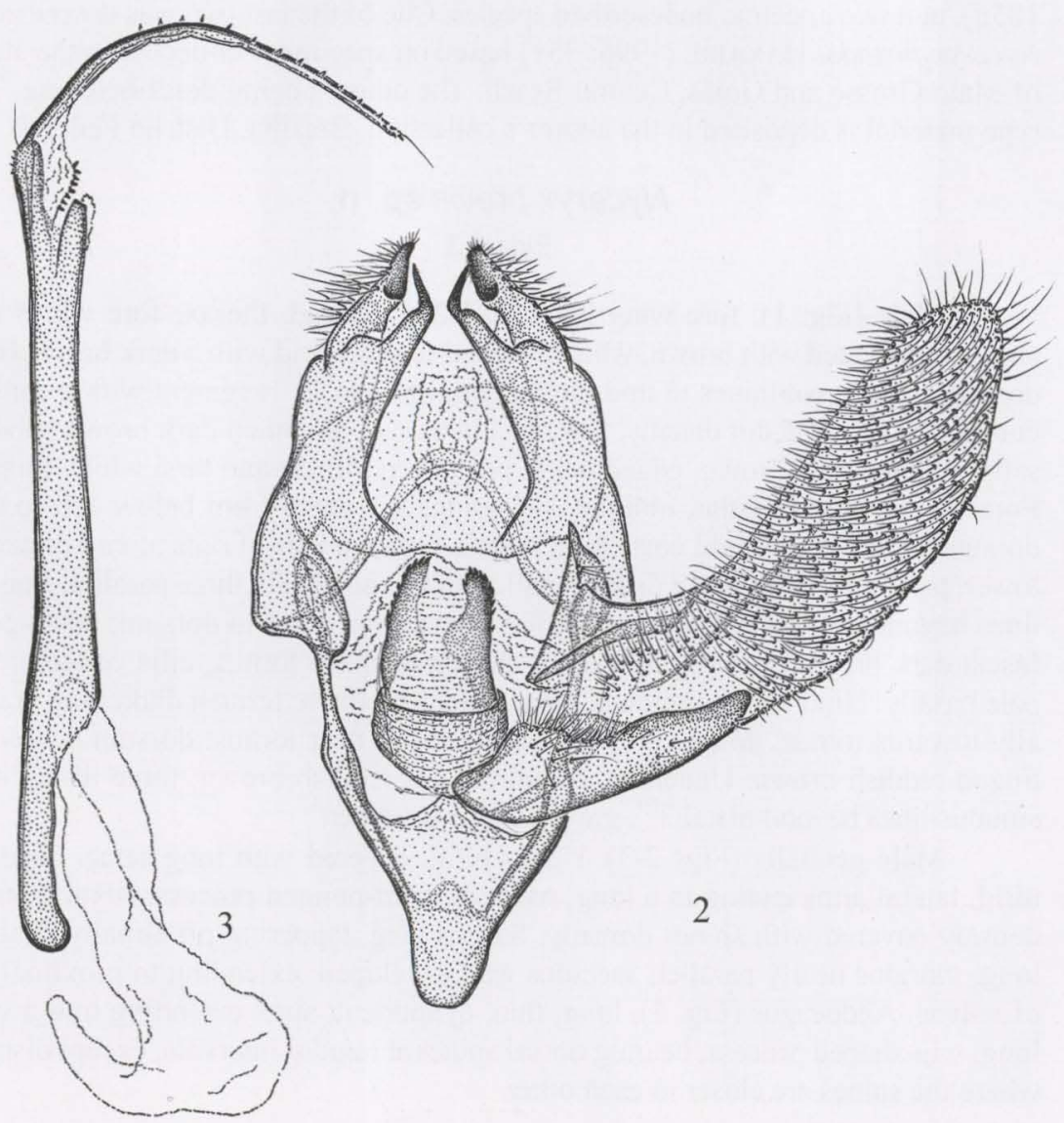

Figs 2-3. Male genitalia of Nyceryx brevis sp. n., paratype. 


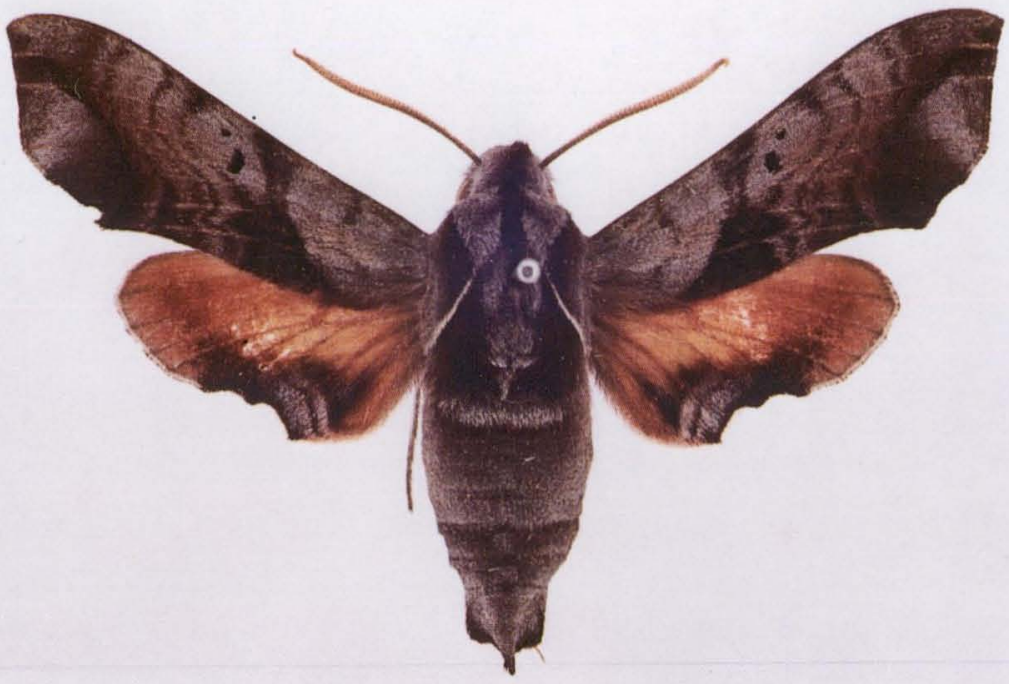

Fig. 1. Adult male of Nyceryx brevis sp. $\mathbf{n}$., holotype, dorsal view.

ACKNOWLEDGEMENTS. The author is most grateful to Wellington Cavalcanti, staff artist, Centro de Pesquisa Agropecuária dos Cerrados (EMBRAPA), for producing the line drawings.

\section{REFERENCE}

H^XAIRE, J. 1996. Description d'un nouveau Sphingidae bresilien: Nyceryx furtadoi n. sp. (Lepidoptera Sphingidae). Lambillionea 46: 351-353.

Recebido em 26.III.2000; aceito em 05.IV.2001 